\title{
The Effects of School Principals' Leadership Style, Work Motivation, and Work Discipline on Teacher Pedagogical Competencies
}

\author{
Rini Mutia ${ }^{1}$, Niswanto ${ }^{2}$, Yusrizal 3 \\ DOI: $10.35445 /$ alishlah.v13i2.530
}

\begin{tabular}{l}
\hline Info Artikel \\
\hline Keywords: \\
Leadership style; \\
Motivation; \\
Discipline; \\
work
\end{tabular}

Kata kunci:

Gaya

kepemimpinan;

motivasi;

disiplin;

kerja

\begin{abstract}
This study aimed to elicit data regarding the effect of school administrators' leadership styles, work motivation, and work discipline on teacher pedagogical competency. This study employs a quantitative methodology. The researchers conducted a quantitative study to demonstrate the effect of the principal's leadership style, work motivation, and work discipline on the pedagogical competency of teachers at SMA Negeri 1 Badar, Aceh Tenggara Regency. The findings indicate that principal leadership has a considerable effect on teacher performance and that teacher work motivation greatly affects teacher performance. Principal leadership and teacher work motivation have a major impact on teacher performance. The purpose of this study was to elicit data regarding the effect of school administrators' leadership styles, work motivation, and work discipline on teacher pedagogic competency. This study employs a quantitative methodology. The researchers conducted a quantitative study to demonstrate the effect of the principal's leadership style, work motivation, and work discipline on the pedagogical competency of teachers at SMA Negeri 1 Badar, Aceh Tenggara Regency. The findings indicated that principal leadership has a substantial effect on teacher performance, that teacher work motivation has a significant effect on teacher performance, and that principal leadership and teacher work motivation significantly affect teacher performance.
\end{abstract}

\begin{abstract}
Abstrak
Tujuan dari penelitian ini adalah untuk memperoleh data tentang pengaruh gaya kepemimpinan, motivasi kerja, dan disiplin kerja Kepala Sekolah terhadap kompetensi pedagogik guru. Penelitian ini menggunakan pendekatan kuantitatif. Peneliti menggunakan kajian kuantitatif karena penelitian ini menekankan pada bagaimana pengaruh gaya kepemimpinan kepala sekolah, motivasi kerja dan disiplin kerja terhadap kompetensi pedagogik guru di SMA Negeri 1 Badar Kabupaten Aceh Tenggara. Hasil penelitian menunjukan bahwa: Terdapat pengaruh yang signifikan kepemimpinan kepala sekolah terhadap kinerja guru, juga menunjukan adanya pengaruh yang signifikan antara motivasi kerja guru terhadap kinerja guru, Terdapat pengaruh yang signifikan antara kepemimpinan kepala sekolah dan motivasi kerja guru terhadap kinerja guru.
\end{abstract}

\footnotetext{
${ }^{1}$ Universitas Syiah Kuala, Banda Aceh, Indonesia

Email : rinimutia15@gmail.com

${ }^{2}$ Universitas Syiah Kuala, Banda Aceh, Indonesia

Email : niswanto@unsiyah.ac.id

${ }^{3}$ Universitas Syiah Kuala, Banda Aceh, Indonesia

Email : yusrizal_fkip@unsiyah.ac.id
} 


\section{INTRODUCTION}

Education is a necessary process for the growth of individuals and society to be balanced and excellent. The growth of education in the community is one indicator of humans' prosperity as individuals and society. The evolution of education in the twenty-first century, or the century of globalisation, has resulted in profound changes to the preceding century's order of life. The development in the 21st century also requires active, creative and quality human resources. Developments in the 21st century require quality human resources produced by professionally managed institutions to produce superior results (Wijaya et al., 2016). Therefore, the process of developing quality human resources will improve the quality of education for the better.

Improving the quality of education is one of the strategies for enhancing a person's or group's quality in terms of their ability to learn. Improving the quality of education is the capacity of educational institutions to maximise their students' learning skills via educational resources (Putra et al., 2017). The obligations and responsibilities associated with developing a high-quality school cannot be divorced from the principal's ability to lead and manage the institution.

Leadership is one of a leader's abilities or endeavours to influence others to progress, develop, and prosper. A leader's ability to safeguard an institution, particularly education, will provide direction to his subordinates to increase the institution's quality. It demonstrates that the principal is the primary actor in educational leadership.

The principal's leadership skills influence the success or failure of education developed at the central or regional levels. The principle is critical in facilitating educational leadership and learning and personally interacting with students as an object of education to be educated (Haris, 2018: 25). Principal leadership is the ability of someone who is given more authority or power to improve the school's quality he leads. This proves that each principal has a different leadership style. The application of the principal's leadership style is determined based on a decision from within the principal.

The principal, as the leader, is a direct example of his subordinates' work actions. Principals who are diligent, conscientious, and concerned about their subordinates will stand out from those who are disinterested, less communicative, or even arrogant toward the school community. One of the principal's leadership objectives is to enhance teacher pedagogical competence. Additionally, school principals have a responsibility to play in raising students' work motivation and discipline, which enables instructors' pedagogical competency to increase appropriately

Mulyono (2018) states that leadership is an aspirational force, a strength of enthusiasm, and a creative moral force, which can influence members to change attitudes so that they are in line with the wishes and aspirations of the leader. Salutondok \& Soegoto (2015) said that leadership is a way for a leader to influence his subordinates to cooperate and work effectively according to working rules. In addition to leadership from a leader to provide direction to subordinates, another important thing is the motivation that drives or moves employees, so they can work together productively and achieve predetermined goals.

The principal leadership style in educational institutions has an important role in teacher pedagogical competencies. Competence is the ability (including a set of knowledge, skills, behaviour) of a person (in this case, teachers and lecturers) in carrying out something, which is obtained through education (owned, mastered, and lived). Ahmad (2019) also said that teacher competence is the ability of the teacher in the form of knowledge, skills, and attitudes that are applied in carrying out the profession as a teacher and educator. Teacher competence refers to the abilities, skills, and ways of acting teachers to manage to learn so that learning can run optimally and the ability to understand and develop the talents of interest of students (Sutisna \& Widodo, 2020). Pedagogy is something related to education (teaching and learning activities). This science is supported by philosophy, sociology, psychology and teaching methodology. 
Several previous studies show that problems in building pedagogical competencies. Many problems arise when pedagogic activities must be carried out with technological tools. Cultural and educational barriers hinder the adoption of technologies in educational practice (Wiziack \& dos Santos, 2021). So, the collaborative pedagogic approach is relevant to the current conditions (Garzón, Kinshuk, Baldiris, Gutiérrez, \& Pavón, 2020;DeLuca, Searle, Carbone, Ge, \& LaPointeMcEwan, 2021). It takes teacher competency improvement activities that lead to self-critical reflection as the implementing agent of educational institutions (Sanchez et al., 2018). Therefore, this study aims to obtain school principals' leadership style, work motivation, and work discipline on teacher pedagogical competencies.

\section{METHODS}

This research uses a quantitative approach. Researchers used a quantitative study because this study emphasised the principal's leadership style, work motivation and work discipline on the pedagogical competence of teachers in SMA Negeri 1 Badar, Aceh Tenggara Regency. This aims to understand, reveal, and explain the various images and phenomena in the field and then summarise them into conclusions based on the research data collected by the researcher through a questionnaire. The sample was taken from the total population of 60 teachers who teach at SMAN 1 Badar, Southeast Aceh Regency. After determining the sample, the next step is to distribute the questionnaire. The questionnaire was then analysed using the multiple linear regression method with the help of the SPSS Version 21 program. The research location is a part that cannot be overlooked because it has an important role in the completeness of the research. For this reason, the authors chose the research location, namely SMA Negeri 1 Badar, Aceh Tenggara Regency.

\section{FINDINGS AND DISCUSSION \\ Instrument Test Results}

The level of validity was tested for significance by comparing the value of $r$-count with the value of r-table. As for the degree of freedom (df) $=n-2, n$ is the number of samples. So, in this case, the magnitude of $\mathrm{df}$ can be calculated as 60-2 or $\mathrm{df}=58$ with $=0.05$, then $\mathrm{r}$-table 0.2144 is obtained, if $r$-count is greater than $r$-table and the value of $r$ is positive, then the statement item is said to be valid. The results of the analysis of the validity test on the three variables $\mathrm{X}$ (leadership style, work motivation, and work discipline) and variable Y (pedagogical competence) as a whole statement item or corrected item-total correlation obtained a value > r-table, meaning that all statement items $\mathrm{X}$ and Y variables are included valid category.

The reliability tests analysis on variables X and Y resulted in Cronbach's Alpha values $>0.6$ (above o.6). It can be concluded that all instruments in this study are reliable or reliable. The normality test in this study was normally distributed. The results obtained are by the basis for making decisions that the data or points spread around the diagonal line and follow the direction of the diagonal line. It can be seen in Figure 1 below: 


\section{Normal P-P Plot of Regression Standardized Residual}

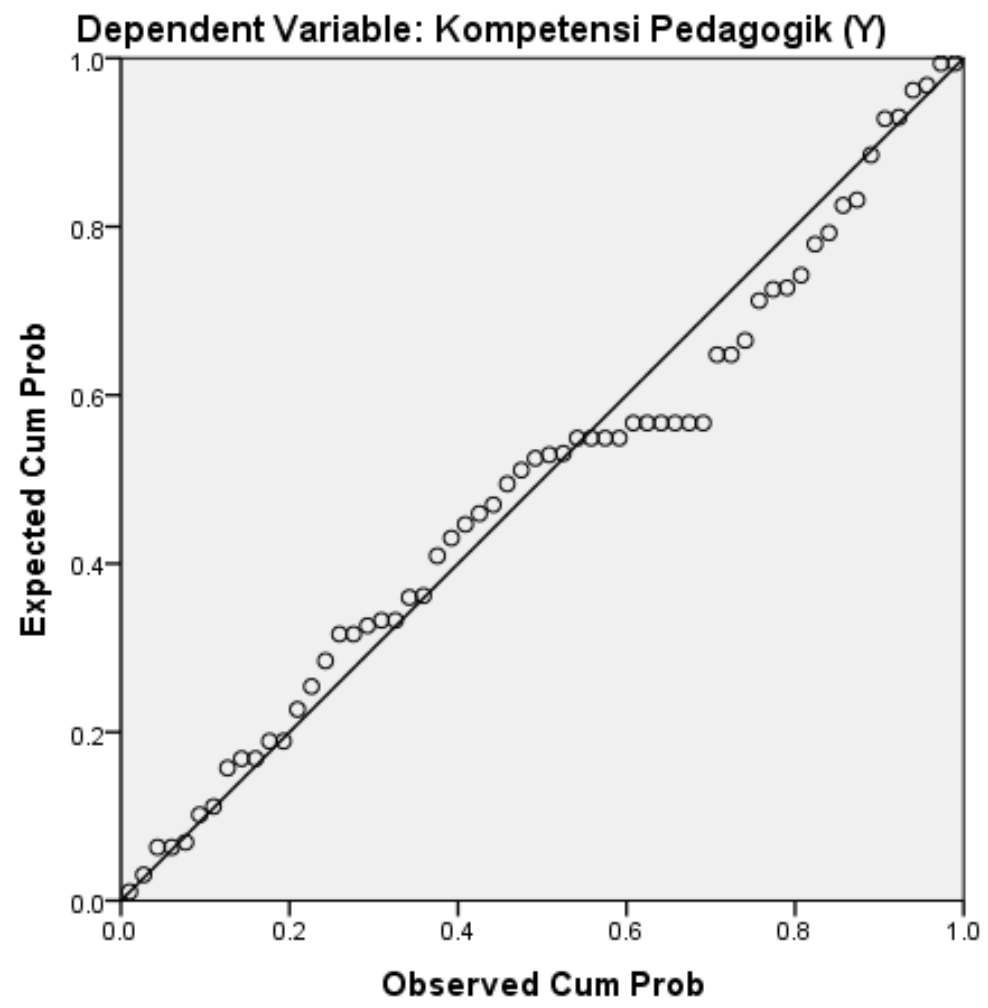

Figure 1. Normality Test

The multicollinearity test conducted in this study aims to test whether the model in the regression found a correlation between the independent variables. A good regression model does not contain multicollinearity. Detecting multicollinearity can see the tolerance value and inflation factor variance (VIF) as a benchmark. If the tolerance value is 0.10 and the VIF value is 10 , it can be concluded that in this study, there is multicollinearity. The results obtained by the value of VIF (Variance Infletion Factor) on the leadership style variable $(\mathrm{X} 1)<10$ then multicollinearity does not occur, while on the work motivation variable (X2) and work discipline $\left(\mathrm{X}_{3}\right)>10$ then multicollinearity occurs.

Based on the results of the computer output through the SPSS program as shown in the table above, the following multiple regression equation is obtained:

$$
\begin{aligned}
& Y=\alpha+\beta_{1} X_{1}+\beta_{2} X_{2}++\beta_{3} X_{3}+\varepsilon \\
& Y=-0,957+0,059 X_{1}+0,664 X_{2}+1,121 X_{3}+\varepsilon
\end{aligned}
$$

From the regression equation above, it can be seen that the research results are:

a. Based on the above equation, the constant value is -0.957. This shows that if the independent variables are assumed to be constant, the pedagogic competence variable increases by -0.957 units.

b. Leadership style (X1) has a value of 0.059. If the leadership style increases by 1 unit, then pedagogic competence also increases by 0.059 units, assuming that other variables are considered constant.

c. Work Motivation (X2) has a value of 0.664 . If work motivation increases by 1 unit, then pedagogic competence will also increase by 0.664 units assuming that other variables are considered constant. 
d. Furthermore, if work discipline $\left(\mathrm{X}_{3}\right)$ is worth 1.121, which means if work discipline has increased by 1 unit, then pedagogic competence will also increase by 1.121 units with the assumption that other variables are considered constant.

The results of the data analysis of the variables of leadership style, work motivation, and work discipline on the pedagogic competence of teachers at SMAN 1 Badar, Southeast Aceh Regency. Based on the value of $t$-count on the three independent variables, it can be concluded that:

a. The effect of leadership style (X1) on the pedagogical competence variable (Y) partially obtained a significance value of $0.586>0.05$ or t-count $(0.547)<\mathrm{t}$-table $(2.003)$, then the decision Ho is accepted, and $\mathrm{Ha}$ is rejected. Thus, it can be concluded that leadership style has no effect and is significant on the pedagogic competence of teachers at SMAN 1 Badar, Southeast Aceh Regency.

b. The effect of work motivation (X2) on pedagogic competence (Y) partially obtained a significance value of $0.042<0.05$ or t-count (2.086) $>\mathrm{t}$-table (2.003), then the decision Ha is accepted, and Ho is rejected. It can be concluded that work motivation has a positive and significant effect on the pedagogic competence of teachers at SMAN 1 Badar Aceh Tenggara

c. Furthermore, the effect of work discipline $\left(\mathrm{X}_{3}\right)$ on pedagogic competence $(\mathrm{Y})$ partially obtained a significance value of $0.001<0.05$ or t-count (3.365) > t-table (2.003). The decision Ha is accepted, and Ho is rejected. Thus, it can be concluded that work discipline has a positive and significant effect on teachers' pedagogical competence at SMAN 1 Badar, Aceh Besar District.

The results obtained illustrate the principal's leadership style, decision-making, division of tasks to subordinates, subordinates' initiative, and giving sanctions/punishments and awarding achievements, establishing communication, monitoring the implementation of tasks and making work meetings. According to research conducted by Giantoro et al. (2019), leadership does not affect teacher performance. This is because the principal has limitations in leading, so he needs staff who can help him by creating an organisational structure with a framework that shows the division of tasks, groupings and lines of coordination.

Robbins \& Coulter (2007) revealed that organisational structure is a formal organisational framework within which work tasks are divided, grouped, and coordinated. The form of organisational structure in schools is generally line and staff organisation, where decisions and policies remain entirely with the principal, but authority is divided on each line. To assist the duties of the principal, there are four deputy principals, namely the curriculum, student affairs, facilities and infrastructure sector, and community and industrial relations, which are assisted by several staff. So the principal's leadership role is indirectly replaced by the role of the vice-principal and his staff.

This is contrary to previous research conducted by Azis \& Suwatno (2019) that the principal's leadership style affects teacher performance. In this case, the teacher's performance measured consists of pedagogic competence, social competence, and personality competence. The research results by Juniarti et al. (2020) say that there is a positive influence between the principal's leadership style and teacher performance. The conclusion shows that the higher the effective leadership style of the principal, the higher the teacher's performance.

Based on the study results, it was shown that the principal's work motivation affected the pedagogical competence of teachers at SMAN 1 Badar, Southeast Aceh Regency. The results obtained prove that the principal's work motivation can be seen in terms of; the need for achievement, opportunities for growth, pride in one's work, the need for recognition, and the salary received by the teacher during the principal's tenure. Research conducted by Harmendi et al. (2021) shows that work motivation positively affects teacher performance. If work motivation is high, the performance results are also high.

The research results by Giantoro et al. (2019) show that work motivation has a positive and significant influence on teacher performance. It means that if the teacher's work motivation is higher, such as the teacher's responsibility in carrying out tasks, carrying out tasks with clear targets, having 
clear and challenging demands, having feedback on work results, having a feeling of pleasure at work, always trying to outperform others, prioritising achievement of what he does, always tries to fulfil his life needs and work needs, likes to get praise for what he does, works with the hope of getting incentives, and works with the hope of getting attention from friends and superiors. It will make teacher performance better.

The results of the research conducted by Sya'roni et al. (2018) that motivation has a significant positive effect on teacher performance. Teacher motivation is an encouragement for the teacher to carry out and complete his work as well as possible. It will happen if the teachers enjoy their work. The work disciplines in this research include; obey and obey school rules, work according to procedures or norms set by the madrasa/school, on time according to the agreed schedule in carrying out tasks, and avoid sanctions or penalties. Previous research conducted by Yenny (2018) shows that discipline significantly affects teaching teacher performance. Thus this value means that partially the Discipline variable has a significant effect on teaching teacher performance. The above concludes that discipline is not only in one workplace wherever the more disciplined employees are in carrying out their duties. The work results produced are also in line with what is desired to impact good work performance.

The research results conducted by Ngiode (2016) that the influence of work discipline on teacher performance directly or indirectly is quite large. Work discipline, which includes punctuality, awareness in work, and compliance with regulations by data processing results, is categorised as quite good. The research results conducted by Wahyudi et al. (2012) say that work discipline is one factor that can affect a teacher's performance. Work discipline is an attitude, an act to always obey the rules.

\section{CONCLUSION}

The research shows that there is a significant effect of principal leadership on teacher performance; There is a significant influence between teacher work motivation on teacher performance; There is a significant influence between principal leadership and teacher work motivation on teacher performance. for further research, the researcher suggests the need to review or include other variables in this study other than pedagogic competence

\section{REFERENCES}

Azuar, Chairul., Syafaruddin., \& Siahaan, Amiruddin. (2017). Manajemen Kepala Sekolah dalam Meningkatkan Fungsi

Guru di

Muhammadiyah 2 Medan. Volume 1, No 2. Tersedia: http://jurnal.uinsu.ac.id/index.php/e duriligia/article/view/896. [18 Oktober 2020].

Ahmad, Edy. (2019). Upaya Meningkatkan Kompetensi Pedagogik Guru dalam Menerapkan Proses Pembelajaran Berbasis Pendekatan Sainstifik Melalui Supervisi Kunjungan Kelas di SMPN 18 Dumai. [Online]. Volume 3, No 4, Tersedia: https://pajar.ejournal.unri.ac.id/index.php/PJR [ 6 Maret 2021].

Akbar, Aulia. (2021). Pentingnya Kompetensi Pedagogik Guru. [Online]. Volume 2, No 1. Tersedia: http://ejournal.uika-bogor.ac.id/index.php/jpg. [6 Maret 2021].

Dirham. (2019). Gaya Kepemimpinan yang Efektif. [Online]. Volume 2, No 1. Tersedia: https://ejournal.iainpalopo.ac.id/index.php/dinamis. [18 Oktober 2020].

Haris, Amin. (2018). Kepemimpinan Pendidikan. Bandung: Alfabeta

Hajar, Siti., Lubis, Rahman, A., \& Lubis, Hineyta Permana. (2018). Pengaruh Perilaku Kepemimpinan dan Kepercayaan terhadap Kinerja Dinas Sosial Tenaga Kera dan Transmigrasi Kabupaten Aceh Barat. [Online]. Volume 2, No 1. Tersedia:http://jurnal.unsyiah.ac.id/JMM/article/view/10241. [18 Oktober 2020].

Hadromi, Al Fathonah. (2017). Analisis Pengaruh Gaya Kepemimpinan Kepala Sekolah terhadap Motivasi, Kedisiplinan dan Kinerja Guru di SD Islam Lumajang. [Online]. Volume 11, No 1. Tersedia:https://jurnal.unej.ac.id/index.php/BISMA /article/view/6212. [5 November 2020]. 
Hadiati, Eti. (2018). Pengaruh Disiplin Kerja terhadap Kinerja Guru MTS Se-Kota Bandar Lampung. [Online]. Volume 8, No $1 . \quad$ Tersedia: http://ejournal.radenintan.ac.id/index.php/idaroh/article/view/3078. [5 November 2020].

Juliantoro, Mohamad. (2017). Peran Kepala Sekolah dalam Meningkatkan Mutu Pendidikan. [Online]. Volume 5, No 2. Tersedia: https://journal.uir.ac.id/index.php/ alhikmah. [18 Oktober 2020].

Kodiran. (2017). Kepala Sekolah Sebagai Tugas Tambahan. [Online]. Volume VII No I. Tersedia: http://ejournal.radenintan.ac.id/index.php/idaroh/index. [18 Oktober 2020].

Mulyono, Hardi. (2018). Kepemimpinan (Leadership) Berbasis Karakter dalam Peningkatan Kualitas Pengelolaan Perguruan Tinggi. [Online]. Volume 3, No 1. Tersedia: https://jurnallp2m.umnaw.ac.id/index.php/JP2SH. [18 Oktober 2020].

Nurhayati, Tati. (2012). Hubungan Kepemimpinan Transformasional dan Motivasi Kerja. [Online]. Volume 1, No 2. Tersedia: https://www.syekhnurjati.ac.id/jurnal/ index.php/edueksos. [18 Oktober 2020].

Putra, Syah Rahmad., Murniati., \& Bahrun. (2017). Stragi Peningkatan Mutu Pendidikan pada SMA Negeri 3 Meulaboh Kecamatan Johan Pahlawan Kabupaten Aceh Barat. [Online]. Volume 5, No 3. Tersedia:http://jurnal.unsyiah.ac.id/JAP /article/view/9024. [18 Oktober 2020].

Sutisna, Deni., Widodo, Arif. (2020). Peran Kompetensi Guru Sekolah Dasar Dalam Meningkatkan Efektivitas Pembelajaran Daring. [Online]. Tersedia: http://ejournal.unp.ac.id/index.php/bahana/article/view/110927. [6 Maret 2021].

Sugiyono. (2018). Metode Penelitian Kuantitatif, Kualitatif, dan $R$ \& D. Bandung: Alfabeta.

Syakir, Junaidi Muhamamad \& Pardjono. (2015). Pengaruh Kepemimpinan Kepala Sekolah, Motivasi Kerja, dan Budaya Organisasi terhadap Kompetensi Guru SMA. [Online]. Volume 3, No 2. Tersedia: https://journal.uny.ac.id/index.php/jamp/article/view/6339. [5 November 2020].

Said, Akhmad. (2019). Kepemimpinan Kepala Sekolah dalam Melestarikan Budaya Mutu Sekolah. [Online]. Volume 2, No 1. Tersedia: https://e-journal.staimaalhikam.ac.id/index.php/evaluasi/article/view/77. [18 Oktober 2020].

Setyaningsih, Kris. (2019). Democratic Leardership: Upaya Kepala Sekolah dalam Membangun Kualitas Peserta Didik di Sekolah Dasar (SD) Tunas Teladan Palembang. [Online]. Volume 4, No 1. Tersedia: journal.uin-suka.ac.id/tarbiyah/manageria. [18 Oktober 2020].

Suharsaputra, Unhar. (2016). Kepemimpinan Inovasi Pendidikan. Bandung: Refika Aditama.

Salutondok, Yohanis., \& Soegoto, Supandi Agus. (2015). Pengaruh Kepemimpinan, Motivasi, Kondisi Kerja dan Disiplin terhadap Kinerja Pegawai di Kantor Sekretariat DPRD Kota Sorong.

[Online].

Volume

No 3. Tersedia:https://ejournal.unsrat.ac.id/index.php/emba/article/view/9659.

Oktober 2020].

Ulya, Wildatun. (2019). Peran Kepala Sekolah dalam Meningkatkan Mutu Pendidikan. [Online]. Volume 8, No 2. Tersedia: http://ejournal.unp.ac.id/index.php/baha na. [18 Oktober 2020].

Utari, Teja Kania \& Rasto. (2019). Pengaruh Disiplin Kerja terhadap Kinerja Guru. [Online]. Volume 4, No 2. Tersedia:https://ejournal.upi.edu/index.php/jpmanper. [5 November 2020].

Usman, Husaini. (2019). Administrasi Manajemen dan Kepemimpinan Pendidikan. Jakarta: Bumi Aksara.

Wijaya, Yuni Estika., Sudijamat, Agus Dwi., \& Amat Nyoto. (2016). Transformasi Pendidikan Abad 21 Sebagai Tuntutan

Sumber Daya Manusia di Era Global. [Online]. Volume 1. Tersedia: http://repository.unik ama.ac.id/840/. [18 Oktober 2020].

Yudiaatmaja, Fridayana. (2013). Kepemimpinan: Konsep, Teori, dan Karakternya. [Online]. Volume 12, No 2. Tersedia:https://ejournal.undiksha.ac.id/index.p hp/MKFIS. [18 Oktober 2020]. 